\title{
Silicon Alleviates Drought Stress of Sugarcane Plants by Improving Antioxidant Responses
}

\author{
Krishan K Verma ${ }^{1-3}$, Rajesh Kumar Singh ${ }^{1-3}$, Qi Qi Song, ${ }^{1,2}$, Pratiksha Singh ${ }^{1-3}$, Bao-Qing Zhang,2, \\ Xiu-Peng Song ${ }^{1,2}$, Gan-Lin Chen ${ }^{1,2}$ and Yang Rui $\mathrm{Li}^{1,2 *}$ \\ ${ }^{1}$ Key Laboratory of Sugarcane Biotechnology and Genetic Improvement (Guangxi), Ministry of Agriculture, Sugarcane Research \\ Center of Chinese Academy of Agricultural Sciences, China
}

${ }^{2}$ Guangxi Key Laboratory of Sugarcane Genetic Improvement, Sugarcane Research Institute, Guangxi Academy of Agricultural Sciences, China

${ }^{3}$ Guangxi Key Laboratory of Crop Genetic Improvement and Biotechnology, China

*Corresponding author: Yang Rui Li, Key Laboratory of Sugarcane Biotechnology and Genetic Improvement (Guangxi), Ministry of Agriculture, Sugarcane Research Center of Chinese Academy of Agricultural Sciences, Nanning, Guangxi - 530 007, China; Guangxi Key Laboratory of Sugarcane Genetic Improvement, Sugarcane Research Institute, Guangxi Academy of Agricultural Sciences, Nanning, Guangxi - 530 007, China, E-mail: liyr@gxaas.net

\begin{abstract}
ARTICLE INFO
Received: 㟒 April 09, 2019

Published: 慧 April 17, 2019

Citation: Krishan K Verma, Rajesh Kumar Singh, Qi Qi Song, Pratiksha Singh, Yang Rui Li, et al., Silicon Alleviates Drought Stress of Sugarcane Plants by Improving Antioxidant Responses. Biomed J Sci \& Tech Res 17(1)-2019. BJSTR. MS.ID.002957.
\end{abstract}

Abbreviations: CRBD: Completely Randomized Block Design; ABA: Abscisic Acid; $\mathrm{GA}_{3}$ : Gibberellic Acid; IAA: Indole-3-Acetic Acid; Si: Silicon
ABSTRACT

Abiotic stress, such as water deficit, is one of the most devastating factors hindering sustainable agricultural crop output today. Plants use their own defensive strategies to cope with the harmful effects of this stress. Silicon is generally considered as a significant element for the growth, development and biomass/ yield production of plants, especially for those grown under stressful environmental conditions. This study was conducted to assess the impact of $\mathrm{Si}$ on antioxidant and phytohormones of sugarcane during water deficit. Experiment arranged as a completely randomized block design (CRBD), was used to examine the effects of two irrigation levels (mild - 75 and severe stress - 30\% of FC and six silicon concentrations consisting of 0, 194, 387, 581, 774 and 968mg Si kg ${ }^{-1}$ soil. Calcium metasilicate $\left(\mathrm{CaO} . \mathrm{SiO}_{2}\right)$ was used as a source of silicon. $\mathrm{CaO} \cdot \mathrm{SiO}_{2}$ addition also enhanced the activities of catalase, peroxidase, superoxide dismutase and phytohormones according to stress intensity and Si doses. The exogenous silicon plays a key role to tolerate water deficit in antioxidant enzymes base, thereby improving overall development and productivity. The results suggest that sugarcane cultivar GT42 is more tolerant to water deficit conditions because of more efficient antioxidant system.

Keywords: Antioxidant Enzymes; Calcium Metasilicate; Phytohormones; Saccharum spp.; Drought

\section{Introduction}

Most of the environmental variables drastically changed to the development of plants [1]. Among abiotic threats, water deficit is one of the special concerns. Water scarcity is a worldwide problem, and thus attracted more attention of the international scientific communities. It is most common in tropical and sub-tropical regions all over the globe and responsible for substantial decline in agricultural crop production. Also, water deficit is one of the most common stress responsible for the changes in morphological, physiological and metabolic activities of plants [2]. Changes in global climatic pattern has similarly escalate the time and period of various environmental factors, i.e. water deficit and maximum intensity of heat, with considerable yield loss in various plants [3]. Sugarcane plant tillering and major growth phages were critical stages of water sensitivity due to demand more water for sustainable plant growth [4]. Silicon (Si) serves as bioactive significant element for agriculture farming. The unlimited benefits of Si to agricultural crops are now well identified [5,6]. Silicon $(28.8 \%$ of dry mass basis) is a main constituent of the Earth's crust following $\mathrm{O}_{2}[2,7]$.

As early as the $19^{\text {th }}$ century the significant impact of Si was apparent to plant biologists. At present many scientific experiments 
have demonstrated that $\mathrm{Si}$ exhibits extraordinary benefits on plant developing stage unequalled by any other non-essential element [8]. Although the importance of this element to crop plants is still debated, there have been significant benefits for plants [9]. Additionally, awareness of the significant effects of supplementing plants with $\mathrm{Si}$ as a soluble form has evolved considerably [6]. Experiment into the effects of Si on plant resistance to environmental stresses such as biotic [10-12] and abiotic [13] stress has approved the findings of the responses of Si on physiological, molecular and ecological base [13-15]. In this research area is apparent in the number of recent scientific reports published on the mitigation of stress by the use of silicon $[2,8,13,16-19]$.

In next coming era, there has been a great demand for bioenergy sources to replace fossil fuels [20]. Sugarcane (Saccharum spp.) is one of the economically important in the world for sugar and bioenergy production [21]. Sugarcane requires favorable environmental variables. Ensuring this water demand under field conditions has been a serious problem since mostly agricultural cultivated land areas suffering from seasonal stress [22]. Plant chemical changes, accumulation of compatible solutes and upregulate antioxidant enzyme activities have been observed as mechanisms or functions that allow plants to avoidance the decrease of water potential in soil $[23,24]$. The importance of antioxidant defense systems has been shown during water deficit conditions [20]. The objective of this experiment was to assess the water deficit tolerant mechanisms on antioxidant and plant hormones activities in sugarcane, therefore revealing the impact of silicon in the mitigation of stress hazards and enhancement of antioxidant enzymes and phytohormones.

\section{Material and Methods}

\section{Growth Condition and Experimental Design}

The experiment was conducted in a greenhouse at Sugarcane Research Center, Nanning, Guangxi, during October to December 2018. Sugarcane (Saccharum spp. L.) plantlets were obtained from Sugarcane Research Center of Chinese Academy of Agricultural Sciences and Sugarcane Research Institute of Guangxi Academy of Agricultural Sciences, Nanning, Guangxi, China. Approximately 45-day-old nursery plantlets were transfered into plastic pots $(30 \mathrm{~cm}$ in diameter, $35 \mathrm{~cm}$ in depth), three plantlets per pot. The pots were filled with fertile soil (air dried) with organic manure, with basal dose of N, P and K (26.0, 1.76 \& 20.0g pot $\left.{ }^{-1}\right)$, kept inside the greenhouse. The substrate elements were analyzed before transplant and treatment, pH-5.92, organic carbon- $0.72 \%$, P-9.18mg kg-1, K-2.71, Ca-4.1, $\mathrm{Mg}^{-1} .6$ and $\mathrm{Na}-0.083 \mathrm{cmol}(+) \mathrm{kg}^{-1}$, respectively. Soil texture was sandy clay. The available content of $\mathrm{Cu}, \mathrm{Fe}, \mathrm{Zn}$ and $\mathrm{Mn}$ were $0.85,12.1,1.31$ and $18.8 \mathrm{mg} \mathrm{kg}^{-1}$. Experiment arranged according to completely randomized block design.

At 75-days after transplanting, thinning was performed, and two plants that exhibited the best well developed were selected. Soil moisture percent was measured by soil moisture meter (TDZ, Top Instruments Co. Ltd., Zhejiang, China). The weather parameters were recorded inside the greenhouse during experiment (Figure 1; Table 1). Sugarcane plantlets were submitted (Table 2) to the following:
a) Mild stress (75\% of FC)
b) Severe stress ( $30 \%$ of FC)
c) 30 -days of stress, followed by 12 days of force stress (without irrigaton)
d) 12-days of force stress, followed by 18 days of rewatering recovery (up to field capacity)

Table 1: Summary of site climate conditions.

\begin{tabular}{|c|c|c|c|c|c|c|c|c|c|}
\hline \multirow{2}{*}{ Climatic Variables } & \multicolumn{9}{c|}{ Experimental Period -2018 } \\
\cline { 2 - 10 } & May & June & July & Aug. & Sep. & Oct. & Nov. & Dec. \\
\hline $\begin{array}{c}\text { Temperature } \\
\left({ }^{\circ} \mathrm{C}\right)\end{array}$ & Maximum & 30.4 & 32.1 & 32.9 & 32.7 & 31.6 & 28.4 & 24.1 & 20.2 \\
\hline & Minimum & 22.8 & 24.9 & 25.4 & 25.2 & 23.6 & 20.2 & 15.3 & 11.3 \\
\hline & Average & 26.6 & 28.5 & 29.1 & 28.9 & 27.6 & 24.3 & 19.7 & 15.8 \\
\hline $\begin{array}{c}\text { Air humidity } \\
(\%)\end{array}$ & Average & 80 & 82 & 82 & 82 & 78 & 75 & 74 & 73 \\
\hline Daylight (h) & Average & 13 & 14 & 13 & 13 & 12 & 12 & 10 & 11 \\
\hline Sunlight (h) & Average & 4.6 & 5.4 & 6.3 & 6.0 & 6.2 & 5.3 & 4.3 & 5.1 \\
\hline
\end{tabular}

Table 2: Twelve treatments $\left(\mathrm{WD} \times \mathrm{CaO} . \mathrm{SiO}_{2}\right)$ designed in this study.

\begin{tabular}{|c|c|c|c|c|c|c|}
\hline \multirow{2}{*}{$\frac{\text { WD (\%) }}{75}$} & \multicolumn{6}{|c|}{$\mathrm{CaO} \mathrm{SiO}_{2}\left(\mathrm{mg} \mathrm{kg}^{-1}\right.$ soil pot $\left.^{-1}\right)$} \\
\hline & $\mathrm{WD}+0^{*}$ & WD+194 & $W D+387$ & $W D+581$ & $W D+774$ & $W D+968$ \\
\hline 30 & $\mathrm{WD}+0^{*}$ & WD +194 & $W D+387$ & $W D+581$ & $\mathrm{WD}+774$ & $W D+968$ \\
\hline
\end{tabular}

WD- water deficit, numbers indicate silicon levels 


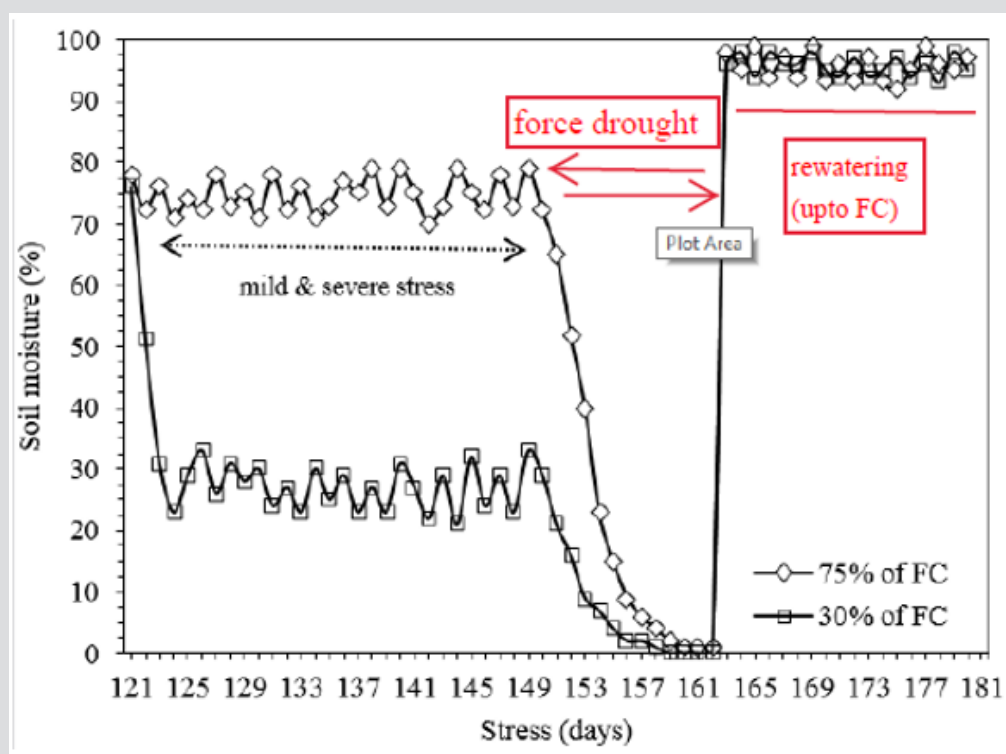

Figure 1: Average soil moisture content (\%) during experiment, monitored by Soil Moisture Meter (TZS), Top Instrument Co. Ltd., Zhejiang, China. Arrow indicate the days of measurement.

Samples of the middle third +1 of the leaf was collected midday at 18-days after rewatering. After washing and drying, immediately frozen in liquid nitrogen and stored at $-80^{\circ} \mathrm{C}$ until analysis.

Proline content was determined according to Bates [25]. Plant samples were homogenized in sulphosalicylic acid $(3 \% \mathrm{w} / \mathrm{v})$ and centrifuged at $6000 \mathrm{~g}$ for $30 \mathrm{~min}\left(25^{\circ} \mathrm{C}\right)$. Two $\mathrm{mL}$ supernatant were mixed to $2 \mathrm{~mL}$ acid ninhydrin solution (ninhydrin-1.25g, glacial acetic acid- $30 \mathrm{~mL}$, phosphoric acid 6M- 20mL) $2 \mathrm{~mL}$ glacial acetic acid and incubated at $100^{\circ} \mathrm{C}$ for $1 \mathrm{~h}$ and quick transferred to an ice bath. The absorbance was recorded at $520 \mathrm{~nm}$, quantified by proline standard curve.

\section{Antioxidant Enzyme Activities}

Frozen samples were homogenized (2:1 buffer $\mathrm{v} / \mathrm{w})$ in a mortar with a pestle with $100 \mathrm{mM}$ potassium phosphate buffer (pH 7.5) containing $1 \mathrm{mM}$ EDTA, $3 \mathrm{mM}$ DL-dithiothreitol and $5 \%(\mathrm{w} / \mathrm{v}$ ) insoluble polyvinylpyrrolidone. The homogenate was centrifuged at $1000 \mathrm{~g}$ for $30 \mathrm{~min}$ and the supernatant was stored at $-80^{\circ} \mathrm{C}$, prior to analysis. To determine the catalase activity [26], the samples were maintained at $4{ }^{\circ} \mathrm{C}$. The reaction was quantified using an UV-spectrophotometer for $1 \mathrm{~min}$ at $240 \mathrm{~nm}$. The reaction medium contained $50 \mathrm{mM}$ phosphate buffer (pH 7.8), $10 \mathrm{mM} \mathrm{H}_{2} \mathrm{O}_{2}$ and $20 \mu \mathrm{L}$ of the extract. The peroxidase activity was determined according to Nakano and Asada [27]. The reaction mixture used in the analysis consisted of $50 \mathrm{mM}$ TFK buffer ( $\mathrm{pH}$ 7.5), $0.1 \mathrm{mM}$ $\mathrm{H}_{2} \mathrm{O}_{2}, 0.5 \mathrm{mM}$ sodium ascorbate and $25 \mu \mathrm{L}$ enzyme extract. Record changes in absorbance of the reaction solution at $290 \mathrm{~nm}$, every 15 $\mathrm{s}$ for $1 \mathrm{~min}$. The method described by Giannopolitis and Ries [28] with some modifications was used for the determination of SOD activity. The reaction medium contained (50 mM TFK, pH 7.8), 13 $\mathrm{mM}$ methionine, $75 \mu \mathrm{M}$ nitro blue tetrazolium, $0.1 \mathrm{mM}$ EDTA, 2.0 $\mu \mathrm{M}$ riboflavin and deionised water with $20 \mu \mathrm{L}$ enzyme extract. One unit of SOD activity was defined as the amount of enzyme required to cause $50 \%$ inhibition of NBT photoreduction quantified at 560 nm by UV-spectrophotometer.

\section{Determination of Phytohormones and Silicon Content}

$1.0 \mathrm{~g}$ leaf samples were ground with an ice chilled mortar and pestle in $5 \mathrm{~mL}$ of methanol $(80 \% \mathrm{v} / \mathrm{v})$ extraction containing $1 \mathrm{mM}$ butylated hydroxytoluene as an antioxidant. The homogenate was kept for $12 \mathrm{~h}\left(4^{\circ} \mathrm{C}\right)$, centrifuged at $10,000 \mathrm{~g}(20 \mathrm{~min})$, and the supernatant was collected. The contents of abscisic acid (ABA), indole-3-acetic acid (IAA) and gibberellins $\left(\mathrm{GA}_{3}\right)$ were determined according to Yang et al. (2001). Silicon content was determined according to Wang [29] with slightly modifications. The fresh leaves were collected, washed and dried up to constant weight. $0.2 \mathrm{~g}$ of crushed leaves from each treatment was digested, using $7 \mathrm{~mL}$ of oxidizing solution $\left(\mathrm{HNO}_{3}-6 \mathrm{~mL}\right.$ and $\left.\mathrm{H}_{2} \mathrm{O}_{2}-30 \%, \mathrm{v} / \mathrm{v}, 1 \mathrm{~mL}\right)$ for 30 $\min \left(150^{\circ} \mathrm{C}\right.$ for 10 and $180^{\circ} \mathrm{C}$ for $\left.20 \mathrm{~min}\right)$. The digested samples were diluted with de-ionized water to final volume $(100 \mathrm{~mL})$ prior to analysis. The Si content was quantified by inductivity coupled plasma-optical emission spectroscopy, calibrated using standard solution.

\section{Statistical Analysis}

All data expressed as the mean \pm standard error, analyzed using ANOVA by GraphPad Prism 8.0.1 software.

\section{Results and Discussion}

Variation in climatic parameters was recorded during study (Table 1). Air temperature and humidity inside the greenhouse were higher as compare to outside, respectively. With respect to these findings, proline content was found significantly higher in drought with $\mathrm{Si}$ as compare to stress without silicon. The higher proline content was increased upto $56.4 \%$ (75\% of $\mathrm{FC}+774 \mathrm{mg} \mathrm{Si}$ ) and $76.7 \%$ (30\% of $\mathrm{FC}+581 \mathrm{mg} \mathrm{Si})$ as compare to 75 and $30 \%$ of $\mathrm{FC}$ to free from Si amendment. The increasing trend was found in both stress situations with silicon. The content of proline further upregulated with Si application (Table 3). Proline, a universal osmoprotectant, acts as both an antioxidant and source of energy [30]. Proline is widely distributed in plants and accumulated in 
more as compared to the other amino acids in stressed plants. The higher proline contents are the main function of the tolerance mechanisms to drought [31]. Similar findings reported in sunflower [32] and potato crops [33].

\section{Effects of Silicon on the Activities of Antioxidative Enzymes}

The activities of CAT, POD and SOD are given in Table 3. The variation of CAT activity was found in 75 and $30 \%$ of FC according to increasing levels of silicon. However, plants exposed to $\mathrm{Si}$ showed to significant upregulate as compare to without silicon in both stresses. In silicon treatment, CAT activity was found highest increment ca. 33 and 22\%. With the progressing leaf development, catalase activity was also increased as relation to free from $\mathrm{Si}$ application. As per Table 3, the enhanced activity of POD was under mild and severe stress with Si treated plants in both conditions. Compared to the stress without Si element, POD activity was found significantly increased up to 50.7 and $62.1 \%$ under 75 and $30 \%$ of FC with $774 \mathrm{mg}$ Si, respectively. Although stress caused an increase in the activity of SOD, it was higher in Si with mild and severe stress treatment as compare to without Si. Compared to 75 and $30 \%$ of FC, application of Si caused an increase such as 34.1 - 61.6 and 46.0 - 88.9\%.

Table 3: Specific activity of proline, catalase (CAT), peroxidase (POD) and superoxide dismutase (SOD) of sugarcane under water deficit conditions with silicon application at 60 days after treatment. The values represent the means of three biological replicates.

\begin{tabular}{|c|c|c|c|c|}
\hline \multirow{3}{*}{$\begin{array}{c}\text { The Potency of CaO.SiO } \\
\left.\text { (mg kg }{ }_{2}^{-1}\right)\end{array}$} & \multicolumn{4}{|c|}{ Proline Content (ng L ${ }^{-1}$ ) Water deficit (\%) } \\
\hline & \multicolumn{2}{|c|}{75} & \multicolumn{2}{|c|}{30} \\
\hline & Mean \pm S.E. & Percent of Control & Mean \pm S.E. & Percent of Control \\
\hline 0 & 2111.26 & - & 3537.14 & - \\
\hline 194 & 2405.28 & 13.93 & 2053.78 & 2.55 \\
\hline 387 & 2347.8 & 11.18 & 2935.84 & 46.60 \\
\hline 581 & 2778.88 & 31.60 & 2002.93 & 76.67 \\
\hline 774 & 3302.81 & 56.42 & 2869.52 & 43.31 \\
\hline 968 & 3249.75 & 53.91 & 2336.75 & 16.68 \\
\hline \multirow{2}{*}{$\begin{array}{l}\text { The Potency of CaO.SiO } \\
\left.\text { (mg kg }{ }_{2}^{-1}\right)\end{array}$} & \multicolumn{4}{|c|}{ CAT $\left(\mathrm{U} \mathrm{mL}^{-1}\right)$} \\
\hline & Mean \pm S.E. & Percent of Control & Mean \pm S.E. & Percent of Control \\
\hline 0 & 10.21 & - & 11.51 & - \\
\hline 194 & 8.92 & -12.63 & 8.46 & -26.50 \\
\hline 387 & 11.51 & 12.73 & 12.75 & 10.77 \\
\hline 581 & 11.29 & 10.58 & 10.55 & -8.34 \\
\hline 774 & 13.62 & 33.40 & 14.03 & 21.89 \\
\hline 968 & 10.21 & - & 10.18 & -11.56 \\
\hline \multirow{2}{*}{$\begin{array}{l}\text { The Potency of CaO.SiO } \\
\text { (mg kg }\end{array}$} & \multicolumn{4}{|c|}{ POD (mU L $\left.)^{-1}\right)$} \\
\hline & Mean \pm S.E. & Percent of Control & Mean \pm S.E. & Percent of Control \\
\hline 0 & 22.89 & - & 19.18 & - \\
\hline 194 & 25.70 & 12.29 & 27.50 & 43.38 \\
\hline 387 & 32.89 & 43.69 & 30.34 & 58.19 \\
\hline 581 & 31.30 & 36.74 & 30.97 & 61.47 \\
\hline 774 & 34.50 & 50.72 & 31.09 & 62.10 \\
\hline 968 & 24.92 & 8.87 & 22.17 & 15.59 \\
\hline \multirow{2}{*}{$\begin{array}{l}\text { The Potency of CaO.SiO } \\
\left.\text { ( } \mathrm{mg} \mathrm{kg}^{-1}\right)\end{array}$} & \multicolumn{4}{|c|}{$\operatorname{SOD}\left(\mathrm{U} \mathrm{L}^{-1}\right)$} \\
\hline & Mean \pm S.E. & Percent of Control & Mean \pm S.E. & Percent of Control \\
\hline 0 & 4306.39 & - & 3507.82 & - \\
\hline 194 & 6274.28 & 45.70 & 5174.22 & 47.53 \\
\hline 387 & 6005.38 & 39.46 & 6628.75 & 88.99 \\
\hline 581 & 5777.22 & 34.16 & 5695.73 & 62.39 \\
\hline 774 & 6958.77 & 61.59 & 5630.54 & 60.54 \\
\hline 968 & 6469.85 & 50.23 & 5121.25 & 46.02 \\
\hline
\end{tabular}

Note: - indicate decrease percent. 
Adaptation to water deficit may depend on various functions, including the capacity to maintain high levels of antioxidants and/ or through the induction of antioxidant enzyme activities. In this experiment, the CAT, POD and SOD enzymes were increased in the sugarcane plant leaves under stress, while such an upregulate was more beneficial and consistent in silicon application as compare to others. Similar results were reported in wheat crop
[34]. However, the application of Si mitigates these harmful effects on plant development by up-regulating the antioxidant enzyme activities [35]. The reduction of oxidative damage through reduced production of reactive oxygen species and/ or enhanced activity of antioxidant metabolism appears to play major role in Si-induced abiotic stress mitigation [2,36-38].

\section{Effects of Si on Phytohormones}

Table 4: Effect of $\mathrm{CaO} . S i O_{2}$ addition on abscisic acid (ABA), indole-3-acetic acid (IAA) and gibberellic acid (GA ${ }_{3}$ ) of sugarcane plant leaves under water deficit condition.

\begin{tabular}{|c|c|c|c|c|}
\hline \multirow{3}{*}{$\begin{array}{c}\text { The Potency of CaO.SiO } \\
\left.\text { (mg kg }{ }^{-1}\right)\end{array}$} & \multicolumn{4}{|c|}{ ABA $\left(\mu g \mathrm{~L}^{-1}\right)$ Water deficit (\%) } \\
\hline & \multicolumn{2}{|c|}{75} & \multicolumn{2}{|c|}{30} \\
\hline & Mean \pm S.E. & Percent of Control & Mean \pm S.E. & Percent of Control \\
\hline 0 & 193.90 & - & 191.80 & - \\
\hline 194 & 254.75 & 31.61 & 245.16 & 28.27 \\
\hline 387 & 235.57 & 21.76 & 201.40 & 5.24 \\
\hline 581 & 356.67 & 84.46 & 286.83 & 49.74 \\
\hline 774 & 416.92 & 115.54 & 333.89 & 74.35 \\
\hline 968 & 304.51 & 57.51 & 229.27 & 19.90 \\
\hline \multirow{2}{*}{$\begin{array}{c}\text { The Potency of CaO.SiO } \\
\left(\mathrm{mg} \mathrm{kg}^{-1}\right)\end{array}$} & \multicolumn{4}{|c|}{ IAA $\left(\mathrm{pmol} \mathrm{L}^{-1}\right)$} \\
\hline & Mean \pm S.E. & Percent of Control & Mean \pm S.E. & Percent of Control \\
\hline 0 & 46.63 & - & 70.94 & - \\
\hline 194 & 54.67 & 17.24 & 66.04 & 6.91 \\
\hline 387 & 50.68 & 8.69 & 67.19 & -5.29 \\
\hline 581 & 41.19 & -11.67 & 50.10 & -29.38 \\
\hline 774 & 47.52 & 1.91 & 56.79 & -19.95 \\
\hline 968 & 40.06 & -14.09 & 52.42 & -26.11 \\
\hline \multirow{2}{*}{$\begin{array}{c}\text { The Potency of CaO.SiO } \\
\left(\mathrm{mg} \mathrm{kg}^{-1}\right)\end{array}$} & \multicolumn{4}{|c|}{$\mathrm{GA}_{3}\left(\mathrm{pg} \mathrm{ml}^{-1}\right)$} \\
\hline & Mean \pm S.E. & Percent of Control & Mean \pm S.E. & Percent of Control \\
\hline 0 & 576.30 & - & 822.69 & - \\
\hline 194 & 695.42 & 20.66 & 762.49 & -7.30 \\
\hline 387 & 529.69 & -8.16 & 810.47 & -1.46 \\
\hline 581 & 505.76 & -12.33 & 824.60 & -0.24 \\
\hline 774 & 695.71 & 20.66 & 846.87 & 2.92 \\
\hline 968 & 516.23 & 9.89 & 756.51 & -8.03 \\
\hline
\end{tabular}

Note: - indicate decrease percent.

Impact of silicon on endogenous plant hormones are commonly assessed in response to stress situation. Our results showed that the activity of plant hormones such as abscisic acid (ABA), indole3 -acetic acid (IAA) and gibberellic acid $\left(\mathrm{GA}_{3}\right)$ were marginally increased and/or decreased in water deficit with silicon as compare to free from silicon (Table 4). The impact of exogenous silicon applied on endogenous phytohormone and their link to stimulatory Si effects on plants has received little attention to till date, and only few scientific reports have been published. In the study performed by Pei [39] also reported that Si enhanced abscisic acid in wheat cultivar during drought condition. These phytohormones, as studies generally indicate, serve to reinforce a plant's capability to hold up against stresses $[40,41]$. Silicon element may enhance the plant tolerance to water stress by adjusting the levels of plant hormones [42,43].

The accumulation of $\mathrm{Si}$ in leaves were found increased (3.6 - 58.2\%) under mild and (3.8 - 55.3\%) severe stress condition with silicon application (Table 5). Silicon has been extensively shown to enhance crop productivity and stress tolerance [44-46]. In this experiment, we found the $\mathrm{CaO} \cdot \mathrm{SiO}_{2}$ addition resulted in an improvement of overall plant development of stressed plants. The results summarized so far indicate that optimizing Si content in plants might be a promising strategy to enhance tolerance against various environmental stresses. Further studies are needed to explore, how silicon triggers the antioxidant defense system in sugarcane under water deficit condition. 
Table 5: Effect of $\mathrm{CaO} . \mathrm{SiO}_{2}$ addition on the silicon distribution within sugarcane plant leaves under drought-stressed conditions. The data values represent the means of four biological replicates.

\begin{tabular}{|c|c|c|c|c|}
\hline \multirow{2}{*}{$\begin{array}{c}\text { The Potency of CaO.SiO } \\
\left(\mathbf{m g ~ k g}^{-1}\right)\end{array}$} & \multicolumn{4}{|c|}{ Silicon Content (mg kg-1 DW) Water Deficit (\%) } \\
\cline { 2 - 5 } & Mean \pm S.E. & Percent of Control & Mean \pm S.E. & Percent of Control \\
\cline { 2 - 5 } & 3.06 & - & 3.40 & 5.88 \\
\hline 0 & 3.73 & 21.90 & 3.60 & 42.06 \\
\hline 387 & 4.84 & 58.17 & 4.83 & 3.83 \\
\hline 581 & 3.17 & 3.60 & 3.53 & 30.88 \\
\hline 774 & 3.40 & 11.11 & 4.45 & 5.28 \\
\hline 968 & 3.68 & 20.26 & 5.28 & \\
\hline
\end{tabular}

\section{Acknowledgement}

We wish to warmly thank Guangxi Academy of Agricultural Sciences (GXAAS), Nanning, Guangxi, China for providing the necessary facilities for this study. This study was supported in part by the Guangxi Research and Development Program Fund (GK17195100), Fund for Guangxi Innovation Teams of Modern Agriculture Technology (gjnytxgxcxtd-03-01) and Fund of GXAAS (2015YT02).

\section{References}

1. Shahbaz M, Ashraf M, Al Qurainy F, Harris PJC (2012) Salt tolerance in selected vegetable crops. Crit Rev Plant Sci 31(4): 303-320.

2. Verma KK, Wu KC, Singh P, Malviya MK, Singh RK, et al. (2019) The protective role of silicon in sugarcane under water stress: photosynthesis and antioxidant enzymes. Biomed J Sci Tech Res 15(2): 1-7.

3. Carmen B, Roberto D (2011) Soil bacteria support and protect plants against abiotic stresses. In: Shan A (Ed.), Abiotic Stress in Plants mechanisms and Adaptations. Pub. In Tech 143-170.

4. Dinh TH, Watanabe K, Takaragawa H, Nakabaru M, Kawamitsu Y (2017) Photosynthetic response and nitrogen use efficiency of sugarcane under drought stress conditions with different nitrogen application levels. Plant Prod Sci 20(4): 412-422.

5. Epstein E (2009) Silicon: its manifold roles in plants. Ann App Biol 155: 155-160.

6. Debona D, Rodrigues FA, Datnoff LE (2017) Silicon's role in abiotic and biotic plant stresses. Ann Rev Phytopathol 55: 85-107.

7. Epstein E (1999) Silicon. Ann Rev Plant Biol 50: 641-664.

8. Frew A, Weston LA, Reynolds OL, Gurr GM (2018) The role of silicon in plant biology: a paradigm shift in research approach. Ann Bot 121(7): $1265-1273$

9. Hodson MJ, White PJ, Mead A, Broadley MR (2005) Phylogenetic variation in the silicon composition of plants. Ann Bot 96(6): 1027-1046.

10. Fauteux F, Rémus-Borel W, Menzies JG, Bélanger RR (2005) Silicon and plant disease resistance against pathogenic fungi. FEMS Microbiol Lett 249(1): 1-6.

11. Reynolds OL, Keeping MG, Meyer JH (2009) Silicon-augmented resistance of plants to herbivorous insects: a review. Ann App Biol 155(2): 171-186.

12. Reynolds OL, Padula MP, Zeng R, Gurr GM (2016) Silicon: potential to promote direct and indirect effects on plant defense against arthropod pests in agriculture. Front Plant Sci 7: 744.

13. Cooke J, Leishman MR (2016) Consistent alleviation of abiotic stress with silicon addition: a meta-analysis. Funct Ecol 30(8): 1340-1357.
14. Detmann KC, Araújo WL, Martins SCV, Sanglard LM, Reis JV, et al. (2012) Silicon nutrition increases grain yield, which, in turn, exerts a feedforward stimulation of photosynthetic rates via enhanced mesophyll conductance and alters primary metabolism in rice. New Phytol 196(3): 752-762.

15. Ma JF, Yamaji N (2015) A cooperative system of silicon transport in plants. Trends Plant Sci 20(7): 435-442.

16. Coskun D, Britto DT, Huynh WQ Kronzucker HJ (2016) The role of silicon in higher plants under salinity and drought stress. Front Plant Sci 7: 1072.

17. Coskun D, Deshmukh R, Sonah H, Menzies JG, Reynolds O, et al. (2019) The controversies of silicon's role in plant biology. New Phytol 221(1): 67-85.

18. Luyckx M, Hausman JF, Lutts S, Guerriero G (2017) Silicon and plants: current knowledge and technological perspectives. Front Plant Sci 8: 411.

19. Etesami H, Jeong BR (2018) Silicon (Si): review and future prospects on the action mechanisms in alleviating biotic and abiotic stresses in plants. Ecotoxicol Environ Safety 147: 881-896.

20. Cia MC, Guimaraes ACR, Medici LO, Chabregas SM, Azevedo RA (2012) Antioxidant responses to water deficit by drought-tolerant and sensitive sugarcane varieties. Ann Appl Biol 161(3): 313-324.

21. Bassi B, Menossi M, Mattiello L (2018) Nitrogen supply influences photosynthesis establishment along the sugarcane leaf. Sci Reports 8: 2327.

22. Chaves MM, Pereira JS, Maroco JP, Rodrigues ML, Ricardo CPP, et al. (2002) How plants cope with water stress in the field: photosynthesis and growth. Ann Bot 89: 907-916.

23. Sairam RK, Rao KV, Srivastava GC (2002) Differential response of wheat genotype to long term salinity stress in relation to oxidative stress, antioxidant activity and osmolyte concentration. Plant Sci 163(5): 10371046

24. Moussa HR, Abdel Aziz SM (2008) Comparative response of drought tolerant and drought sensitive maize genotype to water stress. Aust J Crop Sci 1: 31-36.

25. Bates LS, Waldren RP, Teare ID (1973) Rapid determination of free proline for water stress studies. Plant Soil 39(1): 205-207.

26. Aebi H (1984) Catalase in vitro. Method Enzym 105: 121-126.

27. Nakano Y, Asada K (1981) Hydrogen peroxide is scavenged by ascorbatespecific peroxidase in spinach chloroplasts. Plant Cell Physiol 22(5): 867-880.

28. Giannopolitis CN, Ries SK (1977) Superoxide dismutases. I. Occurrence in higher plants. Plant Physiol 59(2): 309-314.

29. Wang L, Huang X, Zhou Q (2008) Effects of rare earth elements on the distribution of mineral elements and heavy metals in horseradish. Chemosphere 73(3): 314-319. 
30. Matysik J, Alia BB, Mohanty P (2002) Molecular mechanisms of quenching of reactive oxygen species by proline under stress in plants. Curr Sci 82(5): 525-532.

31. Ashraf M (2004) Some important physiological selection criteria for salt tolerance in plants. Flora 199(5): 361-376.

32. Gunes A, Pilbeam J, Inal A, Coban S (2008) Influence of silicon on sunflower cultivars under drought stress, I: growth, antioxidant mechanisms, and lipid peroxidation. Comm Soil Sci Plant Anal 39(1314): 1885-1903.

33. Crusciol CAC, Pulz AL, Lemos LB, Soratto RP, Lima GPP (2009) Effects of silicon and drought stress on tuber yield and leaf bio- chemical characteristics in potato. Crop Sci 49(3): 949-954.

34. Gong HZ, Chen K, Wang S, Zhang C (2005) Silicon alleviates oxidative damage of wheat plants in pots under drought. Plant Sci 169(2): 313321.

35. Siddiqui MH, Al Whaibi MH, Faisal M, Al Sahli AA (2014) Nano-silicon dioxide mitigates the adverse effects of salt stress on Cucurbita pepo $L$. Environ Toxicol Chem 33(11): 2429-2437.

36. Zhu Z, Wei G, Li J, Qian Q, Yu J (2004) Silicon alleviates salt stress and increases antioxidant enzymes activity in leaves of salt-stressed cucumber (Cucumis sativus L.). Plant Sci 167(3): 527-533.

37. Ali A, Haq T ul, Mahmood R, Jaan M, Abbas MN (2016) Stimulating the anti-oxidative role and wheat growth improvement through silicon under salt stress. Silicon, p. 1-4.

38. Kim YH, Khan AL, Waqas M, Lee IJ (2017) Silicon regulates antioxidant activities of crop plants under abiotic-induced oxidative stress: a review. Front Plant Sci 8: 510.

\section{ISSN: 2574-1241}

DOI: 10.26717/BJSTR.2019.17.002957

Yang Rui Li. Biomed J Sci \& Tech Res

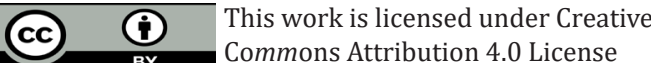

Submission Link: https://biomedres.us/submit-manuscript.php
39. Pei ZF, Ming DF, Liu D, Wan GL, Geng XX, et al. (2010) Silicon improves the tolerance to water-deficit stress induced by polyethylene glycol in wheat (Triticum aestivum L.) seedlings. J Plant Growth Regul 29(1): 106115.

40. Iqbal N, Umar S, Khan NA, Khan MIR (2014) A new perspective of phytohormones in salinity tolerance: regulation of proline metabolism. Environ Exp Bot 100: 34-42.

41. Fahad S, Hussain S, Matloob A, Khan FA, Khaliq A, et al. (2015) Phytohormones and plant response to salinity stress: a review. Plant Growth Regul 75(2): 391-404.

42. Kim YH, Khan AL, Kim DH, Seung Yeol Lee, Kyung Min Kim, et al. (2014) Silicon mitigates heavy metal stress by regulating P-type heavy metal ATPases, Oryza sativa low silicon genes, and endogenous phytohormones. BMC Plant Biol 14: 13

43. Yin L, Wang S, Tanaka K, Fujihara S, Itai A, et al. (2016) Silicon-mediated changes in polyamines participate in silicon-induced salt tolerance in Sorghum bicolor L. Plant, Cell Environ 39(2): 245-258.

44. Gonzalo MJ, Lucena JJ, Hernandez Apaolaza L (2013) Effects of silicon addition on soybean (Glycine max) and cucumber (Cucumis sativus) plants grown under iron deficiency. Plant Physiol Biotech 70: 455-461.

45. Shahbaz M, Ashraf M, Al Qurainy F, Harris PJC (2012) Salt tolerance in selected vegetable crops. Crit Rev Plant Sci 31(4): 303-320.

46. Yang JC, Zhang JH, Wang ZQ Zhu QS, Wang W (2001) Hormonal changes in the grains of rice subjected to water stress during grain filling. Plant Physiol 127(1): 315-323.

$\begin{array}{ll}\text { BIOMEDICAL } & \text { Assets of Publishing with us } \\ \text { RESEARCHES } & \text { - Global archiving of articles } \\ & \text { - Immediate, unrestricted online access } \\ & \text { - Rigorous Peer Review Process } \\ \end{array}$

